\title{
Chapter 9 \\ Transnational Mobility and the Renegotiation of Gender Identities: Albanian and Bulgarian Migrants in Greece
}

\author{
Riki Van Boeschoten
}

Before, in Albania, it was a terrible shame for men to help their wives with the chores. Now that has changed. When I go out to work, my husband washes up all the dishes and even sweeps the floor. (Konstandina, born 1961, interviewed by Alexandra Siotou, 2 May 2006) ${ }^{1}$

I tell my son to find a girl who has not been touched by anyone else. And we still think that the girls from Albania are more suitable to set up a family with. Albanian girls over here don't know how to cook, they prefer to order a pizza from the delivery. They go down to the beach for a coffee. We don't have money for that. And they want equal rights with men. For us, for our generation, that is not right. For our children it may be different. (Illir, born 1958, interviewed by Lambrini Styliou, 7 July 2005)

These two conflicting statements by Albanian migrants in Greece give a good sense of the reshuffling of gender relations going on within the Albanian migrant community. A man and a woman-both born more than 40 years ago in Albania and now living with their families in Greece - speak in quite different terms about their perceptions of the changes in gender relations in their households. While for Konstandina the sharing of the household chores between husband and wife is a positive development, Illir considers the influence of the host society on Albanian migrant families to be a threat to traditional notions of masculinity. In this chapter I use the life stories of 40 adult migrants of both sexes from Albania and Bulgaria to examine the dynamics of gender relations in the context of the migration process.

\footnotetext{
${ }^{1}$ The interviews quoted in this chapter were collected between 2004 and 2007 in the Greek town of Volos. The research project, during which we recorded 60 life stories of migrants from Albania and Bulgaria, was entitled, 'Gendered Aspects of Migration from South-East Europe: Labour, Public Culture and Intercultural Communication' and was financed by the European Commission. For more information, see http://extras.ha.uth.gr/pythagoras1/en/index.asp. All names are pseudonyms and all interviewees have signed a release form by which they grant their interviews to the Laboratory of Social Anthropology of the University of Thessaly.
}

\footnotetext{
R. Van Boeschoten $(\triangle)$

Department I.A.K.A., University of Thessaly, Volos, Greece

e-mail: riboush@uth.gr

(C) The Author(s) 2015. This book is published with open access at SpringerLink.com

H. Vermeulen et al. (eds.), Migration in the Southern Balkans, IMISCOE Research Series, 
Specifically, I discuss two questions that our interview material presented. First, how can we explain the revelation via the interviews of a substantial degree of empowerment for migrant women (in different ways for Albanian and for Bulgarian women) alongside a disempowerment of men (both Albanian and Bulgarian), with obvious signs of a crisis of masculinity? This study seeks to understand this tendency of going against the widespread phenomenon of disempowerment of women in their post-socialist home countries, a trend often termed 'patriarchal backlash'. The second question concerns the striking differences between the discourses, attitudes, and social practices of Albanian and Bulgarian women. Can these differences be explained by the changing status of women in their home country or rather by their position in the Greek labour market? To address these questions the life stories give us important insights into the individually and socially constructed gendered subjectivities of migrant men and women, but they cannot give all the answers. They have to be set against the historical background of the development of gender relations in these two home countries over the last century and the specific migration regime in their host country.

\subsection{Gender and Migration: Some Recent Theoretical Insights}

The increased feminization of migration has been correctly characterized as one of the hallmarks of post-1990 transnational mobility (Castles and Miller 2009, p. 12). Although women were never absent from the migratory flows of the past (Morokvasic 1984), the sheer mass of women on the move, as well as their important role in gender-specific networks of labour migration, has made migrant women more visible and this, in turn, has redressed the gender imbalance of earlier studies (Kofman et al. 2000). Since the 1980s, this global phenomenon has produced an influential new body of work within migration studies, focusing on gender issues and, until the mid-1990s, it focused almost exclusively on female migrants. This work has shown, amongst other things, that women are not just following men in the migration process but are increasingly migrating on their own initiative and for their own reasons, which are often very different from those of their male counterparts. It has also shown that in many cases female migrants' income is not just 'pin money' to supplement the family's budget. Rather, women may take over the predominant male role of breadwinner. It has been suggested that women's employment abroad may contribute to their emancipation and social improvement, but it does not necessarily do so: it may just as easily lead to an increase of the burdens on migrant women or to greater social isolation (Morokvasic 1984). If this was true for the post-war migration flows of the1960s, when most migrant women were largely unskilled and came from rural areas, this ambivalent position is even more in evidence in contemporary migration. In the new globalized settings, migrant women are better educated and more urbanized than their earlier counterparts. They are often deskilled upon arrival in their host country and forced to work in the worst 
paid and most precarious sectors of the labour market, usually in domestic work. They have thus become 'servants of globalization' (Parreñas 2001) and members of a new 'service caste' (Andall 2003).

These women-centred studies have gradually been supplanted by a new focus on gender as an analytical category permeating the whole migration process. This shift was inspired by the understandings brought to the fore by feminist scholarship: that gender does not concern women alone, but the dynamic and contextual relationships between men and women; that it is a power relationship connected to other axes of power beyond the private sphere of the family, such as class, race, and ethnicity; that it is a social construction influenced as much by subjective processes as by structural aspects of the relation between men and women (Donato et al. 2006; Kofman et al. 2000, pp. 21-43).

This concern has also given rise to a recent trend in migration studies of looking at migrant men, no longer as 'normal' gender-neutral subjects of migration, as in the 1970s, but as gendered subjects in their own right. This in turn has led to an emerging body of work on shifting masculinities among men involved in migration processes. Such research may focus, for example, on men left behind at home (Elmhirst 2007; Parreñas 2005), the effects of downward mobility on migrant men employed in low-paid jobs (Datta et al. 2009; Papailias 2003), on male marriage migrants (Charsley 2005), and on male return migrants (Osella and Osella 2000). These studies show that it would be wrong to think of migrant 'masculinity' as a single, homogeneous concept. The construction of male identities is influenced by a variety of factors, such as class, ethnicity, cultural context, and historical developments. Different, conflicting, and shifting masculinities can co-exist within the same migrant community or within the same country, and some authors have proposed a distinction between 'hegemonic' and 'subordinate' masculinities (Charsley 2005; Datta et al. 2009). Yet, beyond these variations, this work has also shown that when migrant men fail to achieve their preconceived ideals of manhood, this may lead to a crisis of masculinity, often compensated for by some form of performative hypermasculinity (Datta et al. 2009, p. 869; Elmhirst 2007, p. 229).

Another emerging trend in gender and migration studies is a focus on familyrelated migration. In the introduction to a special issue of the Journal of Ethnic and Migration Studies, Kofman (2004) notes that this topic is rather surprisingly understudied and has been treated as a subordinate and secondary form of migration, in spite of the fact that over the past two decades it has become the dominant mode of legal entry into the EU. She attributes this neglect to an over-emphasis in migration studies on the individual as an independent, mainly economic, subject (ibid., p. 243). ${ }^{2}$ Kofman explores the implications of changing forms of family-led migration linked to specific phases in the life cycle (family reunification, marriage migration, and retirement or return migration), as well as the increasing restrictions imposed by nation states on this form of migration (ibid.). Here I take a different approach to the role of the family in the migration process. I am mainly interested

\footnotetext{
${ }^{2}$ Greece is no exception to this rule, but see Baldwin-Edwards (2008, pp. 14-16) for data on family arrangements of immigrants based on the 2001 census.
} 
in how shifting gender relations between migrant men and women are embedded in and influenced by kinship and family relations - both prior to migration and after arrival in the host country. The biographical approach adopted in this chapter, based on the life stories of migrants belonging to different age groups, clearly show how gender relations have changed over time and what biographical resources migrants take with them on their journey abroad.

\subsection{Gender Relations in Albania and Bulgaria: Historical Perspectives}

The hierarchical gender and power relations that developed historically within the kinship system of the Western and Central Balkans have been generally defined as 'patriarchy'. According to Kaser (2008, p. 33), pre-modern patriarchy can be understood as a 'complex of hierarchical values embedded in a social structural system defined by both gender and age.... It is based on patrilineality, patrilocality, a patriarchically oriented customary law and the formal subordination of women'. Inheritance rules excluded most women from the transfer of property, and women and children owed strict obedience to their husbands or fathers (ibid., p. 35). Within this system, family forms were characterized by the universality of marriage, young age at marriage for both sexes, high rates of fertility, the co-existence of extended and nuclear households, and a predominance of arranged marriages (ibid., pp. 56-84).

While this description offers an accurate account of the general pattern of gender and family relations in the region until the end of World War II, various factors contributed to a loosening of patriarchal bonds beginning in the twentieth century. The most important of these factors were the effects of the first demographic transition (leading to a drop in fertility and mortality rates), the increase of literacy, urbanization, and mass migration.

The most spectacular changes to patriarchal relations, however, occurred during the socialist period. Balkan communist parties were committed, at least initially, to breaking the impact of customary law, to legislating equality between men and women, and to establishing a new ideal type of family, based on love and partnership instead of hierarchical relations between the sexes. At the socio-economic level they aimed at the modernization of society through industrialization, increased literacy, and generalized access to education for both sexes. These policies led to the nuclearization and urbanization of families, increased education and employment of women, liberalization of divorce and abortion, the reversal of generational relations, and the decline of patrilineality as well as of the honour complex related to it (Kaser 2008, pp. 184-185). However, patriarchy was not abolished — far from it. It was transformed. Communist societies were portrayed as large patriarchal households, with the Communist Party ruling as a 'patriarch' over their dependent members. In the 1960s and 1970s this 'parent state' (Verdery 1996) began to develop pronatalist policies to ensure a labour reserve, to restrict its former liberal policies on abortion and divorce, and to stress once again the 'nurturing' responsibility of 
women and their role as reproducers of the nation (Kaser 2008, p. 135; Verdery 1996, pp. 66-69). In the private sphere, in spite of the multiple interventions of the state in this domain, patriarchal relations persisted to a considerable extent, especially in rural areas.

After the end of communism, inequality between men and women increased once again and a general trend towards the 're-traditionalization' of gender relations was observed. Women were pushed out of the public sphere, both in employment and in politics (Kaser 2008, pp. 218-221). While under socialism they constituted a substantial proportion of the workforce, they were the first to be dismissed, and they suffered the most from restrictions of state welfare benefits (Kaser 2008, p. 192, 212). ${ }^{3}$ When employed, they earned on average 30-50\% less than men (Chakarova 2003, p. 63; Kaser 2008, p. 217). Divorced women, widows, and pensioners were extremely vulnerable. Domestic violence increased as a result of widespread unemployment, poverty, and insecurity. Public attitudes towards domestic violence show considerable support for this practice. In 2008, 36\% of men and 30\% of women in Albania justified wife beating. ${ }^{4}$ In Bulgaria, too, domestic violence has been a widespread phenomenon, although not openly acknowledged (Chakarova 2003, p. 73).

Although the retreat of women from the public sphere was at first the result of state policies and economic hardship, the return to more traditional female tasks in the home is increasingly accepted by both men and women as a legitimate choice. Public discourse extolled the virtues of motherhood and associated the communist experience negatively with the 'double burden' of wage labour and domestic chores and with a perceived loss of 'femininity' (Daskalova 2000; Petrova 1993, p. 24). Thus, the traditional role of the male breadwinner made a resolute come-back. While in 1991 only $20 \%$ of Bulgarian women thought that women should stay at home and not work (Petrova 1993, p. 26), in 1999 this percentage had increased to $46 \%$. The figure for Albania was about the same (Kaser 2008, p. 215).

The impact of the post-socialist transformation, including mass migration, on family relations reveals contradictory tendencies, with marked differences between Bulgaria and Albania. As we shall see below, this differentiation stems partly from developments in the interwar period. Yet, in both countries, the available data do not confirm a return to the patriarchal system that prevailed before World War II; and there are obvious signs of change, as well as continuities with the past. In Albania, universal marriage remains largely unchallenged, but the age at first marriage is on the rise, especially for men (Republic of Albania 2010, pp. 88-93). The fertility rate long remained the highest in the region, but it recently dropped to a similar level as neighbouring countries. ${ }^{5}$ Both trends are obviously related to the massive

\footnotetext{
${ }^{3}$ In Albania and Bulgaria women made up about 50\% of the labour force in 1989 (Kaser 2008, pp. 146-147), but in $199954 \%$ of the unemployed in Bulgaria were women (Chakarova 2003, p. 63; Daskalova 2000, pp. 339-342).

${ }^{4}$ Republic of Albania (2010), Demographic and health survey, Albania, 2008-2009, pp. 280-281. On domestic violence in Albania see also Kaser (2008, pp. 223-224).

${ }^{5}$ In the period 1990-1994 the total fertility rate was 2.7 children per woman, compared to 1.57 in Bulgaria and 1.29 in Greece (Kaser 2008, p. 107). In 2008 it had dropped to 1.6 (Republic of Albania 2010, p. 55).
} 
wave of out-migration. There are no signs of a reconstitution of large extended households, except in some isolated areas in northern Albania. Most individuals, especially those in urban areas, live in nuclear families. ${ }^{6}$ In general, marriage practices are conventional. The divorce rate in Albania, at only $1 \%$, is the lowest in the region (Republic of Albania 2010, pp. 86-87). Cohabitation is rare and not well regarded, but it is on the rise among young middle-class urbanites (Kaser 2008, p. 265). Family life and marriage are held in high esteem (ibid., pp. 260-261), and single mothers are disapproved of (ibid., p. 249). For married couples, most decisions are taken by husband and wife together, but $6 \%$ of women declared they had no say at all in household decisions (Republic of Albania 2010, p. 276). In spite of this rather dismal image of the situation of Albanian women, the life stories of three generations of women recorded by a US researcher in 1994 (Pritchett-Post 1998) also reveal changes in gender relations since the end of World War II. This collection ranges from narratives of older village women who married very young under an arranged marriage to women who broke the rules of patriarchy and lived quite independent lives - among them, partisan women, an ethnologist who never married and travelled across Albania on her own to do research, and three sportswomen. One of the terms these women used to describe the strict rules of patriarchy constraining the lives of other women was 'fanaticism', a term we also encountered in our interviews in Volos. The story told by Efigjeni, born in 1934, and a leading member of a Tirana sports club, illustrates the potentially positive role of emigration in the loosening of patriarchal bonds:

We have tried to be successful at a very difficult period of time, a time of fanaticism. When other girls our age were still wearing veils, we were wearing shorts! My father was emancipated in his views because he had spent ten years in America. All of the children in our family were involved in arts, music and sports. We pursued the passions of youth. (Pritchett-Post 1998, p. 84)

If Albania appears as the most conservative country of south-eastern Europe in gender matters, Bulgaria seems to represent the opposite pole. But Bulgaria too shows clear signs of a deepening crisis of the institution of the family. Some of the differences between these two countries have their roots in developments going back to the interwar period. In Bulgaria the restructuring of society through urbanization and industrialization started long before the socialist period (Kaser 2008, p. 121, 125, 126). At the end of World War II, women already constituted $36 \%$ of the industrial workforce. According to Todorova (1993, p. 32), women were quite well respected because of their active role in production, even if they were still dominated by men. Bulgaria also saw an early increase of literacy among Christian women, reaching $67 \%$ in 1921 (Kaser 2008, p. 92). The country also had an influential women's movement starting in the mid-nineteenth century (ibid., pp. 156-157). As the persistence of traditional gender patterns is stronger in rural areas - a trend largely confirmed by our interview material - the urban-rural divide is an important factor to take into account. During the period of socialist rule, industrialization in Bulgaria led to a mass exodus from the countryside towards the cities. In 1980, only $37.5 \%$ of the population continued to live in rural areas (Brunnbauer and Taylor 2004,

${ }^{6}$ The average size is 3.8 persons per household (Republic of Albania 2010, p. 20). 
p. 189). In Albania, the regime of Enver Hoxha kept rural-urban migration under strict control, aimed at keeping a large percentage of the work force in collectivized agricultural firms in the countryside (Fuga 2000, pp. 45-50). After the end of socialism, the level of urbanization increased significantly in that country. Yet, until today a striking difference remains between the two countries in this respect: according to World Bank data, in 2010, $72 \%$ of Bulgarians lived in cities compared with $28 \%$ in rural areas, whereas the figures for Albania were $48 \%$ and $52 \%$, respectively. ${ }^{7}$

The differences between these two countries in gender and family matters, partly resulting from this demographic structure, is borne out by recent statistical indicators. According to data relevant for the period of our research, Bulgaria scored far better than the other countries discussed in this volume, except for Greece, on the UN Gender-Related Development Index. ${ }^{8}$ Bulgaria also had, together with Greece, the lowest fertility rate in the region, at 1.3 in 2005 compared to 2.2 for Albania and Turkey and 1.6 for the Republic of Macedonia. ${ }^{9}$ Finally, in 2004 Bulgaria had the highest percentage of women in parliament, at $22 \%$ (Kaser 2008, p. 221). Although Bulgarians continue to attribute great importance to family life, they do so to a lesser extent than their Balkan neighbours (ibid., p. 261) and various indicators show that traditional family forms are experiencing a crisis. This is evident, for example, in high divorce rates (reaching 19\% in 2005), declining marriage rates, high rates of births outside wedlock, ${ }^{10}$ and a rise in cohabitation (to $13-15 \%$, Kaser 2008, p. 277). Finally, the Bulgarian public shows more tolerance towards homosexuality, single mothers, and abortion (ibid., p. 228, 248, 249, 258, 259).

At first sight, the mainly statistical data presented in this section seem to support the view that the differences noted between Albanian and Bulgarian migrant women from our interview material can be fully explained by developments in their home country. It would, however, be wrong to consider the dynamics of gender relations in the country of origin and in the host country as two separate components. We cannot neglect the fact that most migrants form part of a transnational family network and that many of the trends observed in the home country may actually be the result of the massive waves of out-migration. As Datta et al. (2009) observe, gender identities travel, but they travel both ways. To get a clearer view of the itineraries of these journeys, I now turn to an analysis of the migrants' life stories.

\footnotetext{
${ }^{7}$ See the World Bank database at http://data.worldbank.org.

${ }^{8}$ The score for 2005 was Greece 24, Bulgaria 50, Albania 61 Macedonia 64, and Turkey 79. The Gender-Related Development Index was introduced in 1995 in order to add a gendered dimension to the UN's yearly Human Development Index. It measures factors such as life expectancy at birth, training, GDP per inhabitant and literacy, broken down by gender. http://hdr.undp.org/en/media/ HDR_20072008_GDI.pdf.

In 2010 the GDI was replaced by the Gender Inequality Index, which measures factors related to reproductive health, participation of women in the labour market, and empowerment (e.g. education, women in parliament). According to these most recent data, among the countries examined in this book, Macedonia ranks first with 23 points (mainly due to the high percentage of women in parliament), Greece second with 24, Bulgaria third (40), Albania fourth (41), and Turkey fifth (77). http://hdr.undp.org/en/statistics/gii/.

${ }^{9} \mathrm{http}: / /$ data.un.org/Data.aspx?d=GenderStat\&f=inID $\% 3 \mathrm{~A} 14$.

${ }^{10}$ Some $18.5 \%$ in 1992 (Kaser 2008, p. 246), over 46\% in 2004 (Vassilev 2005, p. 17).
} 


\subsection{Gendered Journeys: Living Betwixt and Between}

The life stories of migrants from Albania and Bulgaria which we analyse here represent very different migration patterns, rendering a comparative approach quite interesting. While both migration flows were the result of the collapse of communism, their timing, gender composition, and migration systems were very different. Migrants from Albania were initially almost exclusively young men who, right from the beginning of the 1990s, crossed the border illegally. This migration followed the patterns of the pecalba or gurbet system of temporary migration inherited from the nineteenth century (see Hristov, this volume), whereby groups of young men left their villages, leaving behind their wives and sisters to care for the household. This pattern changed radically after 1997 as a result of the internal upheaval in Albania after the collapse of a pyramid investment scheme (King and Mai 2008, p. 46), but also following the first regularization programme of migrants in Greece. Since then the percentage of women migrating from Albania has increased dramatically, and now most Albanian migrants live in families. ${ }^{11}$ In Bulgaria, the collapse of communism did not immediately lead to mass emigration. As our life stories show, many Bulgarians tried first to survive the transition period at home, some of them by opening their own businesses. Moreover, the privatization of state-owned factories and the related rise of unemployment started later in Bulgaria than in Albania. Most of our Bulgarian informants arrived in Greece after 2000. The foremost difference, however, between the two groups concerns gender composition and household structures. While Albanian migration is primarily a family-based phenomenon, the great majority of Bulgarian migrants are adult or elderly women who work as live-ins in Greek households and have left their families behind. Many of them are divorced or estranged from their husbands. They use their wages to support their families and many have, in fact, become the head and breadwinner of a transnational household.

A number of trends can be distilled from our interviews of these migrants, as presented below. The analysis is organized by gender (male and female narratives) and country of origin; it focuses mainly on adults aged between 28 and 60 at the time of the interview. Each subset is preceded by a short description of the narrators' profile.

\subsubsection{Albanian Men: Wounded Masculinities}

We interviewed 13 Albanian men, born between 1954 and 1977. Most of them had crossed the border in 1990 or 1991, when they were in their 20s. Seven were already married, three through an arranged marriage, four for love. Four married later while

\footnotetext{
${ }^{11}$ The proportion of Albanian migrants who are in a married relationship, with or without children, ranges from $61 \%$ in rural areas to $77 \%$ in major cities. Most households are composed of nuclear families, whereas the percentage of extended families ranges from $6 \%$ in large cities to $20 \%$ in rural areas (Baldwin-Edwards 2008, p. 16). Albanian migration to Italy shows a similar trend towards family-based settlement (King and Mai 2008, pp. 88-90).
} 
in Greece, all of them with women they had brought from Albania. Two were still unmarried at the time of the interview. Four grew up in a large patriarchal household, but in Greece all but one were living in nuclear families or alone. All 13 were fairly well educated: eight had completed secondary education, two had some form of continued professional training and two had a university degree; only one had not finished high school. Most of these men were originally from rural backgrounds, but some had later moved to a city for studies. Eight of the thirteen had been employed in Albania prior to migrating, but three of them (a schoolteacher, a policeman, and a forester) were deskilled upon arrival. Five were still adolescents when they came to Greece and had no prior working experience. In Greece, the majority of these men were working in the construction sector, but two became self-employed and one, a physician from Tirana, eventually found employment at a local clinic.

In the narratives of these men we can observe the parallel existence of different and sometimes conflicting kinds of masculinities. A dominant type of narrative that emerges in most of the life stories is a defiant story of independence and male bravado, in which the male body and virility play a crucial role. Such accounts appear in stories about the adventurous journey on foot across the border - presented as a heroic tale of male bravery, defiance, and male companionship; a journey of discovery of a hitherto unknown world, full of promises; and an escape from the constraints of both the communist regime and parental authority. A former schoolteacher from northern Albania, described his decision to leave as a project to 'smash the border' and to 'root out the past' (Bouyar, born 1969, interviewed by Riki van Boeschoten, 30 May 2004). A similar rhetoric appears in stories about Albanian migrants' work experience in Greece, in which the narrators depict a strong male identity, based on bodily strength, endurance, and male working skills. Their work experience is presented as a personal success story of linear progress from apprenticeship to mastery. Work and male labour skills are used as symbolic capital, as a means of moral recognition, and an informal passport into Greek society. ${ }^{12}$ While at first sight this triumphant discourse seems in conformity with traditional Albanian views on male dominance and independence, when seen in the context of the whole life story, it acquires a different meaning: a vindicating counterpoint to a sense of wounded masculinity, which also pervades many of the narratives (see also Papailias 2003).

Accounts about encounters with Greek men, in the workplace or on the street, reveal a different kind of masculinity, a subordinate masculinity, in which notions of class, gender, and ethnicity are intertwined. Living in illegality, as a person 'without a fatherland, without a name, without any rights at all', ${ }^{13}$ being beaten up by police, being contemptuously called a 'dirty Albanian' by colleagues at work, or being refused payment by an employer are all moments of humiliation that are particularly offensive to Albanian men, who grew up in a society built around the notion of male honour. For younger men, being rejected by a Greek girl is perceived as another offence to their sense of male pride.

\footnotetext{
${ }^{12}$ For similar narratives among male migrants to London, see Datta et al. (2009).

${ }^{13}$ Sokratis, born 1977, interviewed by Alexandra Siotou, 28 May 2006.
} 
To compensate for this wounded masculinity, many Albanian men responded by reclaiming their own hypermasculinity or by presenting the self as part of a superior moral community based on traditional patriarchal values. For example, they portrayed their Greek colleagues on a construction site as lazy and feminine. Younger and less experienced Albanian workers adopted this same discourse, albeit with mild self-irony. Besí, a musician, commented on his failure to perform his manhood at work, by stressing his similarity to young Greek workers:

I used to work like the Greeks, taking it easy. You know, have a cigarette. Have a coffee. Because I was only 23 and I had never worked in my life! I'd only played the accordion, never taken a spade in my hands. I had women's hands [he laughs]. And the other Albanian guys were laughing behind my back. I really had a rough time. (Besí, born 1977, interviewed by Pothiti Hantzaroula, 4 July 2005)

Illir criticized Greek men for their soft manners towards their own women folk and was appalled by the fact that Greek women had taken over control. He compared a Greek man lighting his wife's cigarette to a 'mouse' and commented, 'I didn't like the scene. If I caught my wife smoking, I would string her up! Look. I gave up smoking and I'm a man. How on earth could I let my wife smoke?' (Illir, born 1958, interviewed by Lambrini Styliou, 7 July 2005).

Another type of masculinity appears mainly in the narratives of married family men with children. In these narratives, Greek society is portrayed as a dangerous place of pleasures and sexual liberation. They stress the duty of the Albanian pater familias to protect his women folk from these dangers and thus reinforce traditional gender ideologies.

In spite of the fact that the life stories of Albanian migrants clearly show that gender relations changed significantly during the socialist period, especially in the cities and among youngsters who spent time away from their families for studies, the above examples reveal a strong trend of neo-traditionalism. A striking example of this is found in the marriage strategies of young Albanian men who came to Greece as adolescents. Although many had been involved in sexual relationships with Greek women and had gradually developed more liberal attitudes towards gender relationships, when they reached the age to start their own families, they often resorted to traditional practices such as arranged marriages and seeking a 'clean' virgin bride from Albania. In their own words, they were after 'a wife for the home', a condition for which few Greek women would qualify. Besí, whom we met before struggling with the notion of maleness shared by his Albanian colleagues at the workplace, and who had experimented with partnership relations with Greek women while working as a musician in Athens, resorted to more conservative attitudes when considering his own marriage:

In Albania we used to say 'you can't keep a woman, she will let the devil out of the bottle'. But whatever you do, if she sets her mind on something, she will do it... For me the question of virginity is done and finished. It belongs to the past. We have been here for many years and we have adapted ourselves. Yet a woman should be foremost a good housewife. Because only a woman can keep the house. (Besi, born 1977, interviewed by Pothiti Hantzaroula, 4 July 2005) 
Although younger migrants may adopt more liberal attitudes in matters of sexuality - in comparison with older family men, such as Illir (quoted at the beginning of this chapter), for whom virginity is still a crucial question — generally Albanian men insist on the 'good housewife' model and conceptualize gender relations in Greece as a threat to their sense of masculinity. As explained above, this should be seen more as a reaction to perceived humiliations and feelings of insecurity and exclusion in the host country than as an identity process imported from the home country. ${ }^{14}$

\subsubsection{Bulgarian Men: Mixed Masculinities}

Given the preponderance of women in the group of Bulgarian migrants settled in Volos, we were able to interview only five Bulgarian men, born between 1943 and 1975. All but one came from an urban environment. Four had finished a technical school, and one had a university degree. Three had been employed as craftsmen, one was a musician and one had been employed by an advertising firm. After the end of communism, they lost their jobs, but some tried unsuccessfully to set up their own business in Bulgaria. In Greece, two were deskilled: the advertising employee found work as a housekeeper and the musician as a construction worker. Two of the craftsmen (a marble-carver and a carpenter) found similar employment in Greece, while another man who had been a professional truck driver in Bulgaria became a warehouse keeper. Three had prior migration experience. One was a widower, three had been divorced in Bulgaria, and all had a new relationship with a Bulgarian woman (two were married to a second wife, three cohabited without being married).

The Bulgarian men did not dwell on their journey to Greece, although they all came illegally at first, after various failed attempts to cross the border. Most of them walked across the border between the Republic of Macedonia and Greece and then hired a cab to travel to Thessaloniki. Some, however, presented stories of male adventure, bravery, and companionship which were analogous to the heroic border-crossing tales of the Albanian men. These narratives concerned experiences of male labour migration to remote parts of the Soviet Union during the socialist era. Like their Albanian counterparts, Bulgarian adult men attached the utmost importance to their work experience, which they linked to their idea of masculinity. ${ }^{15}$ Yet, in contrast to the Albanians, they drew their self-respect more from their craftsmanship and their sense of initiative than from bodily strength and endurance.

\footnotetext{
${ }^{14}$ For a discussion of similar trends among male migrants in London, see Datta et al. (2009, p. 869). Another interesting parallel is Charsley's (2005) research on the frustrations of Pakistani 'unhappy husbands' who come to Britain to marry a Pakistani migrant woman. By living in their father-in-law's household they are obliged to conform to subordinate forms of masculinity, contrary to Pakistani ideals of manhood, a situation they see as a traumatizing and emasculating (ibid., p. 13).

${ }^{15}$ For the link between work and masculinity in socialist Bulgaria, see Koleva (2008).
} 
This may be partially linked to the nature of their employment in Greece, but it is also related to the ways in which both groups have reconstructed their personal biographies in the present. For Bulgarian men their sense of self is located in their Bulgarian past, while for Albanian men migration often stems from a desire to wipe out the past and to rebuild their lives from scratch. In this sense, proving their worth on the construction site is a crucial component of their embodied and masculine sense of self.

The most interesting aspect of the Bulgarian men's life stories, however, concerns the crucial role of gender relations in their personal lives. These narratives confirm the deep changes brought about in the Bulgarian family during the socialist period. The oldest man, Gencho, who was brought up in a large patriarchal family near Plovdiv, explained that when his wife worked shifts at a factory, he assumed all the household chores and took care of the children,

[I did] everything. I cooked the dinner, cleaned the house, looked after the baby. Everything. You can't... your wife is at work, the baby cries, you don't know what it wants, you need to give it some food. (Gencho, born 1943, interviewed by Raymond Alvanos, 4 March 2006)

Vasiliv, a truck driver, managed to overcome his wounded male pride after his wife emigrated to Greece leaving him for another man. He decided to look after their children alone:

I am a man. Why should I go and look after the children? She left them behind to tie me down. But then I saw she wouldn't come back and I took the children home. And until today I am in charge of them. (Vasiliv, born 1962, interviewed by Lambrini Styliou, 8 June 2005)

As this example clearly shows, the narratives of Bulgarian men illustrate the links between migration and the crisis of the family in post-socialist Bulgaria. Although economic reasons were important in the decisions of all five men to migrate, emotional relationships that developed after failed marriages were equally crucial for three of them - a situation that is usually associated with women rather than men. Moreover, three of them adopted rather unconventional extramarital relationships after their migration. Yet, although they are clearly more liberal in their relations with women than their Albanian counterparts, they have adopted alternative practices more out of necessity than through a change in gender ideology. Overall, they do not question traditional gender roles, at least not verbally, and they develop ideas about manhood similar to those of Albanian men. Although these men have been marked by the loosening of patriarchal bonds in Bulgarian society over the past decades, they have failed to find a new role for themselves.

As we will see more clearly below, in Bulgaria out-migration has disempowered men in a different way than in the case of Albanians. Women experience greater opportunities to find employment abroad. This offers women the possibility to escape a relationship they find oppressive and to build a new life or to support their children independently from their (former) husbands. As a consequence, men feel they have lost control over a relationship in which they once had a dominant role. 


\subsubsection{Albanian Women: Escaping 'Fanaticism'}

We interviewed 15 Albanian women born between 1924 and $1977 .{ }^{16}$ The overwhelming majority (13 of the 15) had been married in Albania, usually in their early to mid-20s. Only five had married for love (one eloped with her future husband), the rest had an arranged marriage. One woman came to Greece to marry a migrant man through an arranged marriage, and only one was still unmarried at the time of the interview. Nearly all of the married women had lived with their parents-in-law prior to their migration, but in Greece all but one were living in nuclear families. Most women migrated to join their husbands in Greece, but two had migrated alone, leaving their husbands at home. One came to join her mother, who had also migrated alone. Only one woman divorced her husband after coming to Greece. The majority of these women (9 of the 15) grew up in a rural environment, but some had moved to a city before migrating. Their level of education is comparable to that of the men. The majority (10) had finished some form of secondary education; just two had only primary education and three had a university degree. Two of the women had no working experience before their migration. Three had been employed as a schoolteacher, three as an office employee, one as a ticket collector, two as a factory worker, and four in agriculture. In Greece nearly all of them found employment as domestic workers. Consequently, about half of the women in our sample were deskilled upon arrival in Greece.

In the life trajectories of these 15 women, the moment of migration appears to be a turning point: even though most of them had been educated and worked for cash in Albania, their personal lives had been embedded in a network of patriarchal relations in which they were supervised by their brothers, husbands, and motherin-laws, as well as by the local community. The life stories of women born in the 1950s and 1960s are dominated by the conflicts generated in this setting between their own individual aspirations and the rules of the patriarchal extended family. The mass migration of young men undermined the formerly unquestioned power relations in extended households, especially the domination of young wives by their mothers-in-law. Many women experienced this as a liberation and were encouraged to follow their husbands abroad. Sofia constructed her earlier self as a rebel openly contesting the constraints of the patriarchal family:

I put my foot down and didn't hold my tongue. I only spent two years with my motherin-law, but to me it seemed they consumed 20 years of my life. Fortunately, the borders opened and we escaped. When I arrived in Greece, I felt I was reborn. (Sofia, born 1968, interviewed by Alexandra Siotou, 11 July 2005)

By contrast, when the patrilocal household is reconstituted in the host country, the 'migration project-as-liberation' might turn into a nightmare. Diana, who decided

\footnotetext{
${ }^{16}$ Only two belonged to the pre-war generation, both of them members of the Greek minority of southern Albania. The almost total absence of this generation in the Albanian migrant population is a result of Greek immigration law which restricts family reunion to spouses and children, but excludes parents. These two grandmothers were much more conservative in their views on gender matters than younger women who reached adulthood during the socialist period.
} 
to marry the first migrant man she could find to escape the control of her brothers, found herself once more ordered about by her mother-in-law and a jealous husband. For her, the only possible escape was to find employment outside the home (Diana, born 1976, interviewed by Lambrini Styliou, 1 April 2005).

Work (puna) is an all-important part of Albanian women's lives. Regardless of their degree of job satisfaction, work in Greece guarantees a certain extent of autonomy that they do not have at home. Especially women from a rural background, employment in another woman's home, in spite of the 'female' character of the work, is an empowering experience (Kofman et al. 2000, p. 123). For village women who used to work in the fields, work back home did not count as work, as it was considered to be part of their domestic chores. Domestic work is transformed into remunerated labour in Greece with fixed working hours and wages. ${ }^{17}$ In their narratives, it is not working skills or pride that appear as core values, but money. It is their money which they can spend according to their own criteria and which allows them to free themselves from the moral standards of their village community, for example, by buying modern, 'feminine' clothes. In this sense, they considerably value the working experience.

In contrast, educated urban women who exercised a profession in Albania view their work in Greece as a downgrading and humiliating experience. They feel trapped in a closed labour market that does not offer them opportunities to practise their skills, owing to the ethnic division of labour. Their narratives convey a strong sense of insecurity, which is linked to the impossibility of their joining the Greek health insurance system independently and thereby obtaining an autonomous residence permit. Therefore, they remain legally dependent on their husbands. Yet even for these educated women, waged labour remains a major pathway to independence and to self-respect. Andrina, who studied economics in Albania and agreed to marry a Greek man through an arranged marriage (they met for the first time at the border), criticized her own decision to marry a man she did not love in order to settle down and become a housewife:

I got fed up with being a housewife... I said to myself, my life is not only to wash up the dishes, to cook the meal. I had other interests, about society. I got involved with educational programmes, with women's associations. But most of all I wanted to work, to be independent. And that is what I tell other women. Don't seek a 'convenient' marriage. Try to find a job first, to be independent and then you can decide to marry. (Andrina, born 1965, interviewed by Raymond Alvanos, 4 February 2006)

Consequently, migration deeply affected the gender awareness of both rural and urban women. It freed them from the control of the extended household, it guaranteed them a certain autonomy through their work, and it taught them different patterns of gender relations through encounters with another culture.

\footnotetext{
${ }^{17}$ Indeed, research on domestic work carried out at the University of the Aegean found that the most important feature of Albanian domestic workers, in comparison with those from Greece and the Philippines, is that they seek to 'professionalize' their work (Papataxiarchis et al. 2009).
} 


\subsubsection{Bulgarian Women: 'Male Women' and Broken Families}

We interviewed seven Bulgarian women born between 1946 and 1977. In contrast to the Albanian women, they all grew up in an urban environment. Their family situations were also very different from the Albanian women's, but quite similar to that of the Bulgarian men. In most cases, broken families were a major reason for migration. Only one woman lived in Greece with her husband and child, and one was still unmarried but migrated to join her mother who had divorced. The other five women had divorced or separated from their husbands before migrating. One of them came to Greece with her second husband, both of them leaving behind a first marriage and children, in order to live as a couple away from their parents who disapproved of the union. Another divorced woman married a Greek man in Greece, a decision she considers 'the worst mistake in my life'. One had a university degree, and the other six had finished secondary education or technical school. All of them had experienced an active professional life in Bulgaria but lost their jobs in the 1990s. One had worked as a schoolteacher, one as a nurse, three had been office employees and two had worked in industry. After their arrival in Greece, they found employment as live-ins caring for the elderly.

In contrast to most of the Albanian women, the narratives of Bulgarian women present us with a complete reversal of traditional patriarchal gender relations. In spite of the closed environment in which most of them work and live as migrants in Greece, their narratives reveal a strong, empowered identity. They present themselves as active heads of their transnational households, and they often speak in unmistakable denigratory terms about the husbands they left behind:

I've got a husband I don't want to see. He is lazy. The only good thing about communism was that it broke the power of the husband and the father. He works and I work. I earn money and so does he. So he can't order me about. (Elena, born 1946, interviewed by Lambrini Styliou, 29 July 2005)

My former husband was a strange person. Lazy! And he always wanted to show off his manliness. Many men are like that. You know, like the Greek song: 'I am a man and I'll have it my own way. ('Eimai andras kai to kefi mou tha kano.' Svetlana, interviewed by Alexandra Siotou, 28 May 2005)

Some women link their present dynamic character to early childhood. Olga, for example, claimed she was born a 'rebel child' always talking back: 'They had to tape down my mouth, because I talked so much' (Olga, born 1971, interviewed by Alexandra Siotou, 26-27 June 2005). In reality, however, the women's life stories revealed a gradual process of emancipation, punctured by various breaking points. Olga, the rebel child, had at first agreed to live with her husband and mother-in-law in a small apartment. Although she was still very young (she married at 17), she managed to convince her husband to go and live with her own parents. Once again, she rationalized this decision with the power of her tongue: 
We were like two cobras to each other. Two women with their tongues! We went through hell from morning to evening. Because I wasn't a chicken to say, 'Yes madam.' She said one, I said three, she said two, I said six!

Svetlana, who was kidnapped by her future husband, agreed to marry him to avoid bringing shame on her family. But after her divorce, she decided to take her fate into her own hands and instead of moving back to her parents' home, started a new life working in a mine: 'My parents insisted, but I wanted to be independent, to be in command. I wanted to show that I am a "male woman", that I can fend for myself.' For Svetlana, the road to emancipation passed through seeking employment in a male sector of the labour market, adopting a male identity and gaining recognition from her male colleagues. Her present-day affirmative self-presentation is constructed around the notion of pride she drew from this experience. In the mine, Svetlana was responsible for regulating the traffic of machinery up and down the shaft. 'I had to handle very big machines. The work was tiring, but I loved it, because I managed. I was proud of this job. Not everybody can do it. ${ }^{18}$

As these stories show, Bulgarian women, in contrast to most of their Albanian counterparts, had already loosened the bonds of patriarchal gender relations prior to migration. The emancipation project of socialist Bulgaria was focused on opening up male sectors of the labour market to women. One of the possibly unintended consequences of this process was the adoption of a 'male' discourse by women. Our research, as well as other ethnographies of Bulgarian migrant women in Athens (Angelidou 2010; Kambouri and Lafazani 2009), reveal that such 'male' discourse also pervaded the narratives of Bulgarian women about their migration experience. Svetlana, in a powerful gendered metaphor describing the muscular power demanded from her in caring for an elderly woman, compared herself to Heracles. Olga presented us with a heroic and definitely 'masculine' account of her work as a waitress in a night bar, where she violently ousted a male client who had called her a 'Bulgarian whore' and made sexual advances, threatening her with a knife.

To some extent, we can see this strong male discourse as a compensation for the humiliation many of these women felt when they found themselves, after a fully independent professional life, once more in a situation of dependency. Svetlana, commenting on her first job in Greece, working in the fields, said she felt like a slave. Olga's life story is constructed as an assertive response to the daily denigratory comments about her country by her second Greek husband.

For other women, however, the 'male woman' symbolized the darker side of the emancipation process brought about during the communist period. Mira, a former nurse and the only woman in our sample who lived in Greece with her family, commented:

We became like men. I don't know anything about electricity, but as none of the men has time to fix it, I'll have to do it. Emancipacija that came with communism has done much harm to women. (Mira, interviewed by Alexandra Siotou, 12 January 2005)

\footnotetext{
${ }^{18}$ For a similar example of women taking pride in 'male' jobs in socialist Bulgaria, see Koleva (2008, p. 43).
} 
In Mira's view, one of the pitfalls of 'emancipacija' was a shifting of all the burdens of caring for the family, including as breadwinners, to women's shoulders. She bitterly concluded: 'That's why all the Bulgarian women are here!' Here, Mira's comments resonate with the criticism voiced by women in post-socialist Bulgaria about the 'loss of femininity' and the 'double burden' imposed on women during socialist rule (Daskalova 2000; Petrova 1993). Mira's views also explain why there is increasing support, as noted above, in Bulgarian public opinion for a return to the traditional role of the male breadwinner.

Another important insight we can gain from comparing the narratives of Bulgarian and Albanian migrant women concerns the migration process itself. Whereas the Albanian women in our sample who migrated alone form an exception and were faced with social outcry, our Bulgarian women migrated almost exclusively through female networks: they usually followed a female relative, in most cases their mother, or a female friend. These 'pioneers' were most often the first in their family to migrate. The explanations offered by our narrators for this 'women-only' migrant world give us deeper insights into the structural changes in family and gender relations in their country of origin. They stress, first of all, that in Bulgaria it is socially much more acceptable, in comparison with Albania, for a woman to migrate on her own and that this is their own independent decision rather than a family strategy. They also explain that most Bulgarian migrants are women because there is no work for Bulgarian men in Greece. There is some truth to this claim: because of the ethnic division of labour, Albanian men have taken up a dominant position in those sections of the labour market open to migrants.

But the social reality hidden underneath this argument is more complex. For most migrant women, migration is either a welcome solution to unsatisfactory marital relations or a necessity because of the vulnerability of single women in their home country. Our narrators explained that it is impossible for a single woman to survive on a meagre state pension, and that the rate of divorce has soared recently because of the increase of alcoholism and domestic violence after 1990. Some women also attributed their divorce to their husband's adultery or to the fact that they were too young (17 or 18) to choose an appropriate partner when they got married. Such reasoning offers new insights into the whole migration process from Bulgaria: the exceptionally high percentage of divorced women in our sample is not only linked to the high rate of divorce in their home country, but suggests that 'broken families' may be a primary motivation for migration. In other words, Bulgarian women in Greece do not seem to represent a cross-section of the Bulgarian female population, but have a specific social profile.

\subsection{Addressing the Questions}

Looking at migration through the lens of family relations rather than focusing on individuals has led us to an important conclusion. It appears that mass emigration from Albania, with more than one third of its population living abroad, has undermined 
the social tissue of society, but the institution of the family has remained intact even though the structure of households has changed. In Bulgaria, however, migration was, to a great extent, the consequence of a severe crisis in traditional family relations. This crisis had already emerged during the last period of communist rule, and it escalated after 1990. With these findings in mind, we can now return to the questions raised at the beginning of this chapter.

The first question concerns the empowerment of migrant women and the disempowerment of migrant men. This seems puzzling, as in their home countries a postsocialist 'patriarchal backlash' has produced the opposite effect. To what extent can we attribute this change in gender relations to the migration process itself? Taking into account the ethnographic data presented above, this question must be answered differently for the Albanian and the Bulgarian cases.

For Albanian migrants, both men and women, migration played a crucial role in the reconfiguration of gender relations. According to our interview data, two factors were major contributors to the empowerment of Albanian women. The reconstitution of their households according to the nuclear family model disentangled women from the power relations of patriarchal extended families in which many had lived prior to migrating. The absence of the mother-in-law, partly owing to Greek immigration law, was experienced by many women as a blessing. Indeed, it often motivated them to migrate in the first place. The second factor was waged labour, which granted working women increased leverage over decisions taken in the household, as well as more individual autonomy. Since the onset of the economic crisis in 2010, which led to mass unemployment in the construction sector, the decisional power of women has further increased, as they are often their family's main breadwinner. We might also suggest a third factor leading to the empowerment of Albanian women, which, however, needs further investigation. While Albanian men usually work together with other Albanian men, Albanian women are exposed to a gender regime different from that in their home country, both through their work in Greek homes and through their children, who are socialized in the Greek education system. These three factors taken together have enabled Albanian women to renegotiate, to a certain extent, their relations with their husbands. Nonetheless, the reunification of Albanian families in the host country, along with the development of social networks based on region of origin, continue to exercise an substantial degree of social control and to constrain the empowerment of Albanian women.

For Albanian men, the new role of their womenfolk is perceived as a factor of disempowerment. In Albania, male honour was - and still seems to be - a crucial marker of male identity. Traditionally, male honour was linked to the role of men as providers and breadwinners and to their position as defender of their family's honour through control of their women's sexuality. This notion of male honour has been threatened in the host country by a variety of factors: unemployment, the sense of insecurity linked to the migration regime, daily humiliations by police and employers, negative stereotypes of migrant men in the media, the image of Greece as a country of sensual pleasure, and the men's inability to shield their women and children from these perceived dangers. As argued above, these experiences in the host country, as well as the increased autonomy of Albanian women, have produced a crisis of masculinity in migrant men, to which many have reacted with 
different forms of hypermasculinity and a return to traditional gender practices and discourses.

In the case of Bulgarian migrants, the disempowerment of men and the empowerment of women are rooted in the past, especially the communist past, rather than being a consequence of the migration process. The migration of Bulgarian women was facilitated both by their earlier emancipation, which enabled them to migrate on their own, and by the Greek migratory regime with its specific demands for Bulgarian female labour. This does not mean, however, that migration has not had an impact on gender identities among Bulgarian migrants. Our narratives reveal that migration amplified the effects of a process that started earlier in the home country and which assumed larger dimensions under the impact of post-socialist transformation. We have suggested that the assertive self-representations of Bulgarian migrant women as 'male women' might be seen as a response to deskilling, the closed environment, and the new situation of dependency in which many of these women found themselves in the host country. For Bulgarian men, the perceived threats to their sense of manhood are less related to their own experiences as migrants in Greece, but stem more from feelings of insecurity in their relations with Bulgarian women and from their inability to assume a new self-respected role in a changed relationship.

The second question concerns the remarkable differences in the gendered subjectivities of the Albanian and Bulgarian migrant women in our sample. These differences can be partly understood by looking at the modalities of the migration process. While Albanian women usually followed their husbands, Bulgarian women migrated alone through mostly female networks. Albanian women live in families, and although they have gained a certain amount of autonomy through employment, they are still under the supervision of their migrant communities. Because of this social control, but also because of Greek immigration law, it is more difficult for them to gain full independence-for example, by seeking a divorce. Many of the Bulgarian migrants had left their family behind and were the head of a transnational household which included their married children but not their (former) husbands. They migrated due to economic necessity, but also out of desire to change their personal life or to support children.

However, this is only part of the explanation. New insights can be gained if we focus on migration as an interaction between the cultural capital that these female migrants have brought from their home countries and the new challenges they face in their host country. To do this, we should also take into account the historical developments that have influenced gender relations in their country of origin. As this chapter noted, the empowerment of Bulgarian women started much earlier, and the modernization project of the communist regime had a more profound impact on gender relations in Bulgaria than in Albania. Post-communist transformation in Bulgaria deepened the crisis of traditional family relations, whereas in Albania the family remained intact, even though it was affected by a number of structural changes (e.g., nuclearization of families, drop in fertility rates, and the rise of age at first marriage). A final important factor is the rural-urban divide. Although the level of education of Albanian and Bulgarian migrant women is comparable, most Albanian women were raised in a rural environment, while all Bulgarian women in our 
sample grew up in cities. This social profile of migrant women reflects the overall situation in their countries: Albania is still predominantly a rural country, while in Bulgaria the majority of the population lives in cities. ${ }^{19}$

By way of conclusion, I would like to make a few remarks about the implications of the renegotiation of gender identities among Albanian and Bulgarian migrants during the process of their integration into Greek society. Although Albanian migrants have adjusted remarkably well to their new environment - as can be observed, for example, in their command of the Greek language and in the relative success of their children in the Greek education system - their social contacts remain mostly restricted to members of their own kin. One of the reasons invoked by Albanian migrants (mostly by men, but also by some women) to explain this 'embeddedness' has to do with gender: they want to protect their families from the extreme permissiveness, as they see it, of Greek gender relations. In the context of the present economic crisis, mass unemployment has confronted Albanian families with a painful dilemma: to leave or to stay? Once again, gender plays an important role in the choices made by individual migrants, and these decisions are different for men and for women. Men are more eager to return, and many have done so. They may hope to re-establish their self-respect by finding employment or setting up a business and thus to mend their 'wounded masculinity'. Albanian women do not want to go back for fear of returning to the 'fanaticism' that they have tried so hard to escape and because they do not want to be separated from their children for whom Albania is a foreign country.

Most Bulgarian women are also focused on their families - but in a different way - and they seldom seek integration into Greek society. With their remittances they try to build a better future for their children back home, and their social relations in Greece are mostly with other Bulgarian women. Although some Bulgarian women want to remain in Greece and construct a new personal life, most plan to return, but as independent women. Taking into account the improved economic conditions back home after Bulgaria's accession to the EU, this may appear to be an increasingly viable option.

Open Access This chapter is distributed under the terms of the Creative Commons Attribution Noncommercial License, which permits any noncommercial use, distribution, and reproduction in any medium, provided the original author(s) and source are credited.

\section{References}

Andall, J. (2003). Hierarchy and interdependence: The emergence of a service caste in Europe. In J. Andall (Ed.), Gender and ethnicity in contemporary Europe (p. 39-59). Oxford: Berg.

Angelidou, A. (2010). Otan oi yinaikes taxidevoun: yinaikeia metanastefsi apo ti Voulgaria, oikonomikes praktikes kai emfyles taftotites(When women travel: Female migration from Bulgar-

\footnotetext{
${ }^{19}$ Our research did not include Bulgarian women working in agriculture, most of whom come from a rural environment. Many of them are members of Pomak or Roma communities.
} 
ia, economic practices and gender identities). In E. Avdikos (Ed.), Laikoi politismoi kai sinora sta Valkania (Popular cultures and borders on the Balkans) (pp. 159-190). Athens: Pedio.

Baldwin-Edwards, M. (2008). Immigrants in Greece: Characteristics and issues of regional distribution. Working Paper 10. Athens: Mediterranean Migration Observatory.

Brunnbauer, U., \& Taylor, K. (2004). Creating a "socialist way of life": Family and reproduction politics in Bulgaria, 1944-1989. Continuity and Change, 19, 283-312.

Castles, S., \& Miller, M. J. (2009). The age of migration: International population movements in the modern world (4th revised ed.). Houndmills: Palgrave \& Macmillan.

Chakarova, V. (2003). Development of gender relations in the context of social transformation: The case of Bulgaria. www.iehei.org/bibliotheque/memoires/CHAKAROVA.pdf. Accessed 6 February 2012

Charsley, K. (2005). Unhappy husbands: Masculinity and migration in transnational Pakistani marriages. Journal of the Royal Anthropological Institute, 11(1), 85-105.

Daskalova, K. (2000). Women's problems: Women's discourse in Bulgaria. In S. Gal \& G. Kligman (Eds.), Reproducing gender: Politics, publics, and everyday life after socialism (pp. 337 369). Princeton: Princeton University Press.

Datta, K., McIlwaine, C., Herbert, J., Evans, Y., May, J., \& Wills, J. (2009). Men on the move: Narratives of migration and work among low-paid migrant men in London. Social \& Cultural Geography, 10(8), 853-873.

Donato, K., Gabaccia, D., Holdaway, J., Manalansan, M., \& Pessar, P. (2006). A glass half full? gender in migration studies. International Migration Review, 40(1), 3-26.

Elmhirst, R. (2007). Tigers and gangsters: Masculinities and feminised migration in Indonesia. Population, Space and Place, 13, 225-238.

Fuga, A. (2000). Identités périphériques en Albanie: La recomposition du milieu rural et les nouveaux types de rationalité politique (Regional identities in Albania: The recomposition of the rural environment and new types of political rationality). Paris: L'Harmattan.

Kambouri, N. \& Lafazani O. (2009). To spiti sti Voulgaria, i sylloyi me papoutsia stin Ellada: dia-ethnikes diadromes, metanastefsi kai filo (A home in Bulgaria and a collection of shoes in Greece: Transnational trajectories, migration and gender). In D. Vaiou \& M. Stratigaki (Eds.), To Filo tis Metanastefsis (The gender of migration) (pp. 39-66). Athens: Metaichmio.

Kaser, K. (2008). Patriarchy after patriarchy: Gender relations in Turkey and the Balkans, 15002000. Vienna: LIT.

King, R., \& Mai, N. (2008). Out of Albania: From crisis migration to social inclusion in Italy. New York: Berghahn Books.

Kofman, E. (2004). Family-related migration: A critical review of European studies. Journal of Ethnic and Migration Studies, 30(2), 243-262.

Kofman, E., Phizacklea, A., Raghuram, P., \& Sales, R. (2000). Gender and international migration in Europe. London: Routledge.

Koleva, D. (2008). "My life has been spent working": Notions and patterns of work in socialist Bulgaria. Anthropological Notebooks, 14(1), 27-48.

Morokvasic, M. (1984). Birds of passage are also women. International Migration Review, 18(4), 886-907.

Osella, F. \& Osella, C. (2000). Migration, money and masculinity in Kerala. Journal of the Royal Anthropological Institute, 6, 117-133.

Papailias, P. (2003). "Money of kurbet is money of blood": The making of a "hero" of migration at the Greek-Albanian border. Journal of Ethnic and Migration Studies, 29(6), 1059-1078.

Papataxiarchis, E., Topali, P., \& Athanasopoulou, A. (Eds.). (2009). Kosmoi tis oikiakis ergasias: Filo, Metanastefsi kai politismikoi metaschimatismoi stin Athina tou proimou 21 ou aióna (Worlds of domestic work: Gender, migration and cultural transformations in Athens in the early 21st century). Athens: Alexandreia.

Parreñas, R.S. (2001). Servants of globalization: Women, migration and domestic work. Stanford: Stanford University Press.

Parreñas, R. S. (2005). Children of global migration: Transnational families and gendered woes. Stanford: Stanford University Press. 
Petrova, D. (1993). 'The winding road to emancipation in Bulgaria'. In N. Funk \& M. Mueller (Eds.), Gender politics and post-communism: Reflections from Eastern Europe and the former Soviet Union (pp. 22-29). London: Routledge.

Pritchett-Post, S. E. (1998). Women in modern Albania: Firsthand accounts of culture and conditions from over 200 interviews. Jefferson: McFarland.

Republic of Albania (2010). Demographic and health survey, Albania, 2008-2009. Tirana: Institute of Statistics, Institute of Public Health.

Todorova, M. (1993). ‘The Bulgarian case: Women's issues or feminist issues?'. In N. Funk \& M. Mueller (Eds.), Gender politics and post-communism: Reflections from Eastern Europe and the former Soviet Union (pp. 30-38). London: Routledge.

Vassilev, R. (2005). 'Bulgaria's demographic crisis: Underlying causes and some short-term implications'. Southeast European Politics, 6(1), 14-27.

Verdery, K. (1996). What was socialism and what comes next? Princeton: Princeton University Press.

Riki Van Boeschoten is Professor of Social Anthropology and Oral History at the University of Thessaly, Greece. Her research interests include memory, refugee studies, migration and ethnicity, civil war conflicts and post-socialism. She has directed a research programme on gender and migration from Albania and Bulgaria (http://extras.ha.uth.gr/pythagoras1/en/index.asp). Her most recent book, Children of the Greek civil war: Refugees and the politics of memory, co-authored with Loring Danforth, was published by Chicago University Press, 2011. Website: users.ha.uth. gr/boeschoten. 